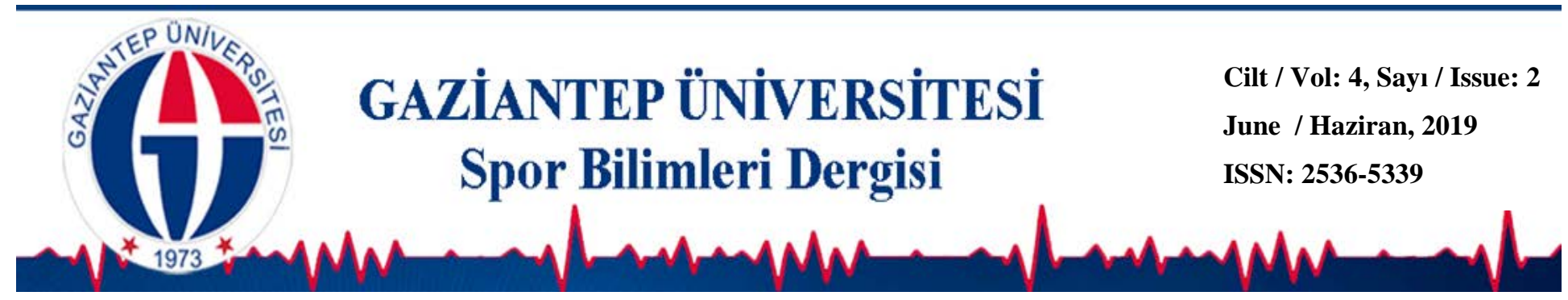

\title{
Sporda Yetenek Seçimi ve Spora Yönlendirmede 9-10 Yaş Çocukların Fiziksel Özellikleri ve Performans Profillerinin İncelenmesi: Kırıkkale Örneği
}

\author{
${ }^{1}$ Kırıkkale Üniversitesi, Spor Bilimleri Fakültesi, KIRIKKALE \\ ${ }^{2}$ Hitit Üniversitesi, Sağlık Bilimleri Enstitüsü, ÇORUM \\ ${ }^{3}$ Ankara Üniversitesi Spor Bilimleri Fakültesi, ANKARA \\ ${ }^{4}$ Akdeniz Üniversitesi, Spor Bilimleri Fakültesi, ANTALYA
}

Aziz GÜÇLÜÖVER ${ }^{1 *}$ (D) İrem Nur ŞAHIN ${ }^{2}$ (D) Mehmet GÜLÜ ${ }^{3}$ (D) Hüseyin Tolga ESEN (D)

DOI: $10.31680 / g a u n j s s .513784$

Orijinal Makale / Original Article

Geliş Tarihi / Received: 16.01.2019 Kabul Tarihi / Accepted: 18.04.2019ＹＩayın Tarihi / Published: 28.06.2019

Öz

Bu araştırmada 9-10 yaş grubu çocukların fiziksel özellikleri ve bazı performans profilleri incelenerek yetenek değerlendirmesinin yapılması, yetenek ve sporcu seçiminde antrenör ve beden eğitimi öğretmenlerinin bu konuda yapılacak olan çalışmalarına katkıda bulunması amaçlanmaktadır. Araştırmanın örneklemini Kırıkkale Merkez Şehit Ramazan Akçadağ İlköğretim Okulunda öğrenim gören ( $n=12$ erkek) ve ( $n=18$ kız) oluşturmaktadır. Katılımcı çocuklara fiziksel ve performans verilerini tanımlamada eurofit test bataryası ve bazı antropometrik ölçümler yapılmıştır. İstatistiksel analizlerde verilerin normalliği Shapiro-Wilk testiyle anlaşılmıştır. Katılımcılara verilerin tanımlanmasında tanımlayıcı istatistik yöntemi ve guruplar arası karşılaştırmalarda ise bağımsız örneklem t-testi uygulanmıştır. Yapılan tanımlayıcı istatistiksel analizler sonucunda katılımcıların antropometrik

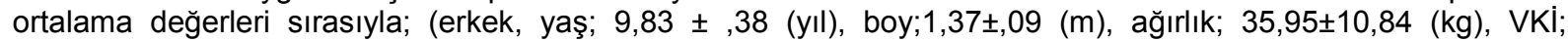
$18,61 \pm 3,70$ ) ve (kız, yaş; $9,83 \pm, 38$ (yıl), boy; $1,39 \pm 0,8(\mathrm{~m})$, ağılık; $35,25 \pm 10,47(\mathrm{~kg})$, VKI; $17,86 \pm 3,94$ ) olarak bulunmuştur. Bununla birlikte bağımsız örneklem t- testi sonuçlarında çocuk katılımcıların sadece sağ bacak otureriş esneklik testinde kızlar lehine $(p<0,05)$ düzeyinde ve dayanıklılık mekik koşusu testinde ise $(p<0,01)$ düzeyinde erkekler lehine anlamlı farklılık tespit edilmiştir.Bu sonuçlar bize ilköğretim çağı çocukların fiziksel ve performans verilerinde cinsiyetler bakımından benzer özellik ve gelişim düzeylerine sahip olduğunu göstermektedir.

Anahtar Kelimeler: Yetenek seçimi, çocuk, eurofit testleri, antropotmetri

\section{The Selection of Talent in Sport and Analysis of Some Physical Characteristics and Performance Profiles of 9-10 Age Children in Sport Orientation: Kırıkkale Sample}

\begin{abstract}
The aim of this study is to evaluate the physical characteristics and some performance profiles of 9-10 age group children in sport selection and directing to sport and to contribute to the studies of coaches and physical education teachers in the selection of talent and athletes. The students of Kırıkkale Central Martyr Ramazan Akçadağ Primary School ( $\mathrm{N}=12$ men) and ( $\mathrm{N}=18$ girls) constitute the sample of this study. Eurofit test battery and some anthropometric measurements were performed to identify physical and performance data for the participating children. The normality of data in statistical analysis is tested usingthe Shapiro-Wilk test. Descriptive statistical methods were used to define the data and independent sample t-test was used for comparisons between groups. According to the results of descriptive statistical analysis, the average anthropometric values of

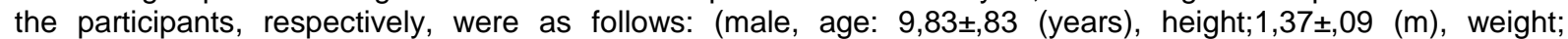

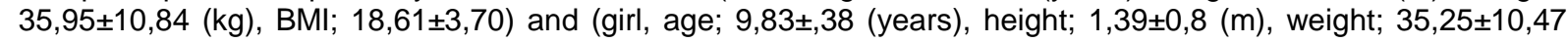
$(\mathrm{kg}), \mathrm{BMI} ; 17,86 \pm 3,94$ ) were found. However, in the independent sample $\mathrm{t}$ - test, there was a significant difference in the right leg sit and reach flexibility test of the participants for girls $(p<0.05)$ and in the endurance shuttle run test for boys $(p<0.01)$. These results show that primary school children have similar characteristics and developmental levels in terms of gender in their physical and performance data.
\end{abstract}

Key words: Talent selection, child, eurofit tests, anthropometry

\footnotetext{
* Sorumlu Yazar: Aziz GÜÇLÜÖVER
}

E-mail: azizgucluover@hotmail.com 


\section{Giriş}

Spor yetişkinlerin sağlıklı yaşam sürmesinde etkili olduğu kadar çocuğun büyümesinde, olgunlaşmasında, bilişsel gelişiminde ve sosyalleşmesinde de önemli rol oynadığı için kişinin hayatına erken yaşlarda girmesi önemlidir (Muratlı, 2013). Sağlıklı yaşama olan etkisinin yanı sıra başarılı sporcuların yetiştirilmesinin de ön koşulu spora başlama yaşındaki çocukların yeteneklerinin uygun zamanda keşfedilmesidir. Böyle bir seçimde hem antrenör hem sporcu hem de ülke zaman kaybetmeyecektir. Aksine başarıya ulaşma zamanı kısalacak ve kolaylaşacaktır. Çocukların yeteneklerine uygun şekilde seçilmesi sağlık, biyometrik nitelikler veya antropometrik ölçümler, genetik, spor imkânları, iklim ve uzmanların varlığı gibi ölçütlere bağlıdır (Tutkun, 2007). Çocuk ve gençlerde uygulanan fiziksel ve fizyolojik testler, planlı fiziksel aktivitenin büyüme, gelişme ve sağlık üzerindeki etkisini ölçmek ve ergenlik dönemindeki çocukların eğitilebilirliklerini incelemek amacıyla kullanılmaktadır. Çocukların büyüme, gelişme ve fiziksel uygunluk modellerinde uzun süreli eğitimleri ve onların farklı şiddet seviyelerindeki egzersizlere yanıtları da fiziksel uygunluk testleri aracılığıyla belirlenebilmektedir (Docherty, 1996). Günlük yaşamda sıklıkla anlamları birbiri ile karşılaştırılan büyüme ve gelişim sözcükleri, gerçekte birbirinden farklı değişimleri içeren kavramlardır. Genel olarak büyüme, kişinin boy veya vücut ağırlığı gibi özelliklerinde meydana gelen değişimleri ifade etmektedir. Dolayısıyla büyümede sadece bedensel bir gelişme söz konusudur (Hasırcı ve ark., 2009). Çocukların mümkün olan en erken yaşta spora yönlendirilmeleri hem büyüme ve gelişme hem de sporda üstün performans elde etme açısından önem arz etmektedir (Tutkun, 2002).

Yetenek kavramı ise çok yönlü ve değişik hareket örneklerine sahip olan, bu örnekleri çeşitli durumlarda çabuk ve doğru kullanabilen, değişik ve yaratıcı kombinasyon yapabilen, ayrıca anında öğrenme ve kavrama özelliği olarak tanımlanmaktadır. Yetenekli kişi ise belirli bir alanda normalin üzerinde olan ancak henüz tam olarak gelişmemiş özelliklere sahip olan kişidir. Yetenekli kişinin yeteneklerinin saptanması genel analizler, sübjektif değerlendirmeler ya da istatistiksel teknikler ile sağlanmaktadır (Tutkun, 2007). Çocuğun gelişim aşamalarını sağlıklı sürdürmesi ve sporda yüksek performans elde edilmesi yeteneğinin doğru bir şekilde tespit edilmesine bağlıdır. Tüm spor branşlarında başarı sporcunun fiziki ve fizyolojik karakterinin belirlenmesi sonucunda elde edilir (Heimer ve ark.,1988; Sallis 
Güçlüöver A., Şahin İN., Gülü M., Esen HT. (2019). Sporda Yetenek Seçimi ve Spora Yönlendirmede 9-10 Yaş Çocukların Fiziksel Özellikleri ve Performans Profillerinin İncelenmesi: Kırıkkale Örneği. Gaziantep Üniversitesi Spor Bilimleri Dergisi, 4(2), 199-210.

ve Patrick, 1994). Sporcuları birbirinden ayıran en önemli unsurlardan biri de yetenektir. Yetenekli bir sporcu ile daha az yetenekli bir sporcu arasındaki farklar; antrenman başarıları arasındaki farklar, aynı kapsam ve büyüklükteki antrenman uyaranları karşısındaki başarı farklılıkları, performansın sürekliliği ve antrenmanda verilen uyaranlara gösterilen uyum hızı, riski göze alma durumu, başarısızlık karşısında sergiledikleri davranış biçimleri olarak belirlenmiştir (Muratlı, 2013).

Yeteneğin seçimi kadar önemli olan yeteneğin eğitimi de spor pratiği açısından son derece önemlidir. Karl (2001), yetenek seçimi ve eğitimi alanında yapılan çalışmaların spor pratiği konusundaki yararlarını; antrenörün çalışma etkinliğinin sporcusunun yeteneğine bağlı olarak artmasında ve bununla birlikte yüksek performanslı sporcu sayısını ve sporcular arasındaki rekabet ve motivasyonunun artmasında bilimsel seçim süreciyle yetişmeyen sporculara oranla daha yüksek özgüvene sahip olduklarını belirtmiştir. Her bir spor dalı farklı özelliklerin bir arada bulunmasını gerekli kılar. Her bir branşta sporcunun farklı nitelikleri ön plana çıkar. (Pekel, 2007). Eurofit test bataryaları ise 6-12 yaş arası okul çağı çocuklarının fiziksel uygunluklarını ölçmek ve değerlendirmek amacıyla Avrupa Konseyi Bakanlar Komitesi tarafından 19 Mayıs 1987 günü aldığı 87 sayılı kararıyla Avrupa Fiziksel Uygunluk Testlerinin (European Test of Physical Eurofit) kullanılması ve bu uygulama ile ilgili tedbirlerin alınması konusunda üye ülkelere tavsiyede bulunulmuştur. Türkiye'nin de aralarında bulunduğu üye ülkelerde bu kararlar sonucunda eurofit test bataryaları uygulanmaya başlanmıştır (Uzuncan, 1991).

Küçük yaşta spora başlamanın sporda beklenen başarıya ulaşmadaki en önemli etken olduğu araştırmalar tarafından desteklenmektedir. Çocuğun spora olan ilgisini ve motivasyonunu arttırmak demek çocuğun ileriki yıllarda sporla iç içe olmasını sağlamak demektir (Muratlı, 2013). Ancak her bir branşın başlama yaşı kendine özgüdür, tek bir yaş tavsiyesi mümkün değildir. Bu nedenle spora başlama yaşı önemli bir sorundur. Çocukların hem gelişim sürecinde hem de yetişkinlik döneminde sağlıklı bir yaşam sürmeleri için erken yaşta spora başlamaları önemli bir konudur. $\mathrm{Bu}$ nedenle bu araştırmada sporda yetenek seçiminin belirlenmesinde kullanılan çeşitli testlere göre 9-10 yaşlarındaki çocukların psikomotor becerilerinde hazır bulunuşluk gerçekliği göz önünde bulundurularak değerlendirmesi yapılmış, yetenek ve sporcu seçimi yapacak olan antrenör ve Beden Eğitimi öğretmenlerine bu konuda yapacakları çalışmalar için katkıda bulunma amacı güdülmüştür. 


\section{Yöntem}

$\mathrm{Bu}$ araştırma nicel araştırma yöntemlerinden deneysel araştırma modeli ile tasarlanmıştır.

\section{Katılımcılar}

$\mathrm{Bu}$ araştırmanın örneklem gurubunu Kırıkkale Merkez Şehit Ramazan Akçadağ İlköğretim Okulu'nda öğrenim gören 12 erkek ve 18 kız öğrenci oluşturmaktadır. Araştırmaya katılmadan önce çocuk katılımcıların ailelerinden yazılı izin belgesi alınmış ve araştırmaya gönüllü katılımları sağlanmıştır.

\section{Verilerin Toplanması}

Araştırmada çocuk katılımcılara fiziksel uygunluk özelliklerinin ve performans profillerinin belirlenmesinde bazı antropometrik ölçümler ile eurofit test bataryası uygulanmıştır.

Antropometrik Ölçümler: Katılımcıların vücut ağırlıkları dijital baskül ile kilogram cinsinden, boy uzunlukları elektronik boy ölçer ile santimetre cinsinden ölçülmüştür. Katılımcıların vücut kitle indeksi değerleri ise $\mathrm{kg} / \mathrm{m}^{2}$ formülü ile hesaplanmıştır.

\section{Eurofit (FitnessGram)Test}

Flamingo Denge Testi: Araştırmada genel denge testi için flamingo denge testi uygulanmıştır. Boyutları $50 \mathrm{~cm}$ uzunluğunda, $4 \mathrm{~cm}$ yüksekliğinde ve $3 \mathrm{~cm}$ genişliğinde olan kiriş üzerinde tek ayak üzerinde 1 dakika içinde kaç saniye dengede kaldığı hesaplanmıştır. Her bir çocuk için test iki kez uygulanarak en iyi derece kayıt edilmiştir (Zahner, 2006).

Otur-Uzan Testi: Katılımcıdan oturur vaziyette mümkün olduğunca gövdesini ileriye esnemesi istenmiş ve ısınması için izin verilmiştir. Üzerinde 0-50 cm aralıklı cetvelli bir kasa kullanılmıştır. Katılımcı bir bacağı 90 derece dik diğeri 180 derece uzanmış halde ayak tabanı kasaya değecek şekilde öne uzanarak ulaştığı son nokta not edilmiştir. Aynı işlem diğer ayak için de uygulanmıştır. Bu işlem iki kez uygulanarak en iyi derece kayıt edilmiştir (Opstoel ve ark., 2015).

Mekik Testi: Katılımcı sırt dik durumda, eller boyunda olacak şekilde mekik pozisyonu aldıktan sonra araştırmacının ayakları sabit ve başlayabilirsin komutu ile 
Güçlüöver A., Şahin İN., Gülü M., Esen HT. (2019). Sporda Yetenek Seçimi ve Spora Yönlendirmede 9-10 Yaş Çocukların Fiziksel Özellikleri ve Performans Profillerinin İncelenmesi: Kırıkkale Örneği. Gaziantep Üniversitesi Spor Bilimleri Dergisi, 4(2), 199-210.

30 saniye boyunca mekik çekmesi istenmiştir. Bu süre sonundaki mekik sayısı not edilmiştir (Zahner, 2006).

Disklere Dokunma Testi: Katılımcıdan ayakları açık vaziyette bir masanın önünde durması ve önündeki iki disk arasındaki dikdörtgen plakaya bir elini koyup diğer eli ile bir sağdaki bir soldaki disklere mümkün olan en kısa sürede 25 vuruş gerçekleştirmesi istenmiştir. Bu işlem diğer el için de uygulanmış ve iki kez tekrarlandıktan sonra puan her bir diske 25 kez dokunabilmek için kullanılan süre olarak belirlenmiş ve saniyenin ondalığı olarak kaydedilmiştir (Zahner, 2006).

Bükülü Kol Asılma Testi: Katılımcının boyuna göre sıçramadan erişebileceği şekilde 2,5 cm çapında ve yuvarlak yatay bir bar iskele hazırlanmıştır. Katılımcıdan başparmak altta diğer parmaklar üstte (serçe tutuş) barı tutması istenmiş ve araştırmacı tarafından çenesi bar hizasının altına gelinceye kadar yardım edilmiştir. Katılımcı çenesi barı altına düşmeyecek şekilde mümkün olduğu kadar barı tutması istenmiş ve gözler barın altına düştüğü anda teste son verilmiştir. Araştırmacının katılımcıyı bırakıp gözlerin barın altına indiği ana kadar geçen süre kaydedilmiştir (Zahner, 2006).

10x5 Metre Koşu Testi: Katılımcıdan 5 metre ara ile belirlenen iki huni arasında olabildiğince hızı koşması istenmiştir. Katılımcı ilk huniden ikinci huniye oradan birinci huniye koşmuş ve bu işlem 50 metreye ulaşana kadar 5 tur şeklinde devam etmiştir. Koşu süresi kayıt edilerek 10x5 metre koşu testi sonlandırılmıştır (Opstoel ve ark., 2015).

El Kavrama Testi: Katılımcıların el kavrama kuvvetini belirlemede (Takei TKK 5101; Takei Scientific Instruments, Tokyo, Japan) dijital dinamometre kullanılmıştır. Test standart pozisyonda (otururken kolları vücudun yanına salarak avuç içi ile dinamometreyi sıkma) hem sağ el hem de sol el için gerçekleştirildi ve en iyi sonuç kg cinsinden kaydedildi (Molenaar ve ark., 2009).

Durarak Uzun Atlama Testi: Yere çizilen çizginin önünde katılımcı ayakta duruş pozisyonunda beklemiş ve kendini hazır hissettiğinde öne doğru sıçraması istenmiştir. Katılımcının ilk durduğu noktadan sıçradığı noktaya kadar topuğunun arkasında kalan yer arasındaki mesafe ölçülerek kaydedilmiştir. Bu test iki kez tekrar edilmiş ve en iyi sonuç kaydedilmiştir (Altınkök, 2006).

Dikey Sıçrama Testi: Katılımcıların dikey sıçrama yüksekliği kuvvet platformu (Force plate Accupower version 2.0 USA) kullanılarak ölçülmüştür. Teste 
Güçlüöver A., Şahin İN., Gülü M., Esen HT. (2019). Sporda Yetenek Seçimi ve Spora Yönlendirmede 9-10 Yaş Çocukların Fiziksel Özellikleri ve Performans Profillerinin İncelenmesi: Kırıkkale Örneği. Gaziantep Üniversitesi Spor Bilimleri Dergisi, 4(2), 199-210.

başlamadan önce katılımcılardan kuvvet platformu üzerinde kıpırdamadan dik pozisyonda durmaları istenmiş bu aşamadan sonra abalakov dikey sıçrama yoluyla mümkün olduğunca yükseğe sıçramaları istenmiştir. Abalakov patlayıcı kuvveti, kasların elastik bileşenini ve kaslar arası koordinasyonu ölçer ve serbest hareket eden kolları kullanır. Katılımcılara abalakov dikey sıçrama testi üç tekrar yaptırılmış ve en yüksek değer alınmıştır (Zahner, 2006).

Mekik Koşu Dayanıklıık Testi: Bip testi olarakta adlandırılan mekik koşu testi kardiyovasküler zindeliği ve maksimum oksijen alımını $\left(\mathrm{VO}_{2}\right.$ max) ölçmek için kullanılan çok aşamalı bir uygunluk testidir. 20 metrelik mekik koşu testi belirli bir koşu hızında başlamakta ve kademeli olarak koşu hızı artmaktadır. Standart test 21 seviyeye sahiptir ve her seviye farklı sayıda mekikten oluşur. Test, 20 metre aralıklı iki işaret çizgisi arasında, bip sesleriyle gösterilen şekilde artan bir koşu hızında gerçekleştirilir. Testin başlangıcındaki koşu hızı 8.5 km / saattir ve koşu hızı kademeli olarak dakikada $0.5 \mathrm{~km}$ / saat artmaktadır. Sporcuların istemli yorulmasına kadar ya da ardışık iki durumda sporcuların belirlenmiş olan zamanda çizgiye ulaşmada başarısız olmasına kadar mekik koşusu devam etmektedir. Test artık hızınızı koruyamadığınızda veya seviye 21 tamamlandığında sona erer. Sonuçlar ve puanlama ardışık bip sesine ulaşamadan önce tamamladığınız son seviye ve mekiktir (Zahner, 2006).

\section{Verilerin Analizi}

Bu araştırmada verilerin analizi için için SPSS 18 paket programı kullanılmıştır. Araştırmaya katılan deneklerin bazı antropometrik özelliklerine ait minimum, maksimum, aritmetik ortalama, standart sapma verilerinin saptanmasında tanımlayıcı istatistik yöntemi kullanılmıştır. Verilerin normalliği Shapiro-Wilk testiyle anlaşılmış ve guruplar arası karşılaştırmalarda ise bağımsız örneklem t-testi uygulanmıştır.

\section{Bulgular}

Araştırmada yapılan tanımlayıcı istatistiksel analizler sonucunda katılımcıların antropometrik verilerine ait ortalama değerleri sırasıyla; (erkek, yaş; 9,83 \pm ,38 (yıl),

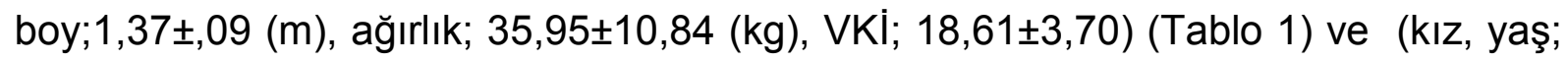

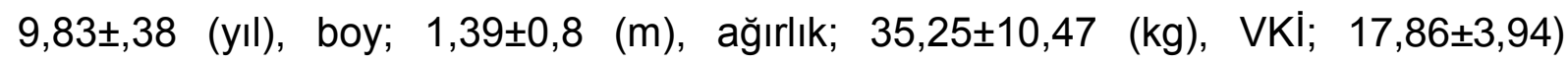
bulunmuştur (Tablo 2). Bunun yanında guruplar arası karşılaştırmalar için bağımsız 
Güçlüöver A., Şahin İN., Gülü M., Esen HT. (2019). Sporda Yetenek Seçimi ve Spora Yönlendirmede 9-10 Yaş Çocukların Fiziksel Özellikleri ve Performans Profillerinin İncelenmesi: Kırıkkale Örneği. Gaziantep Üniversitesi Spor Bilimleri Dergisi, 4(2), 199-210.

örneklem t-testi analiz sonuçlarında katılımcıların sadece sağ otur-eriş esneklik testinde kızlar lehine $(p<0,05)$ düzeyinde ve dayanıklılık mekik koşu testinde ise $(p<0,01)$ düzeyinde erkekler lehine anlamlı farklılıklar tespit edilmiştir. Diğer parametrelerde ise anlamlı fark gözlemlenmemiştir (Tablo 3).

Tablo 1. Erkek katılımcıların antropometrik özelliklerine dair tanımlayıcı istatistikler

\begin{tabular}{lccccc}
\hline Erkek & $\mathrm{n}$ & $\min$ & $\max$ & Ort. & Std.sapma \\
\hline Yas & 12 & 9,00 & 10,00 & 9,83 &, 38 \\
Boy & 12 & 1,23 & 1,55 & 1,37 &, 09 \\
Ağırlık & 12 & 23,00 & 53,65 & 35,95 & 10,84 \\
VKi & 12 & 13,94 & 24,49 & 18,61 & 3,70 \\
\hline
\end{tabular}

Tablo 2. Kız katılımcıların antropometrik özelliklerine dair tanımlayıcı istatistikler

\begin{tabular}{lccccc}
\hline Kız & $\mathrm{n}$ & $\min$ & $\max$ & Ort. & Std.sapma \\
\hline Yas & 18 & 9,00 & 10,00 & 9,83 &, 38 \\
Boy & 18 & 1,28 & 1,59 & 1,39 &, 08 \\
Ağırlık & 18 & 20,40 & 58,30 & 35,28 & 10,47 \\
VKi & 18 & 11,89 & 27,35 & 17,86 & 3,94 \\
\hline
\end{tabular}

Tablo 3. Katılımcıların eurofit test verilerinin karşılaştırılması

\begin{tabular}{|c|c|c|c|c|c|}
\hline Değişkenler & Grup & $\mathrm{N}$ & Ort. & Std. Sapma & P-değeri \\
\hline \multirow{2}{*}{ Durarak Uzun Atlama (cm) } & Erkek & 12 & 99,58 & 18,77 & \multirow{2}{*}{,42 } \\
\hline & $\mathrm{K} \mathrm{IZ}$ & 18 & 105,33 & 19,14 & \\
\hline \multirow{2}{*}{ 10x5 Koşu (m) } & Erkek & 12 & 24,20 & 3,93 & \multirow{2}{*}{,13 } \\
\hline & $\mathrm{K} \mathrm{IZ}$ & 18 & 25,93 & 2,25 & \\
\hline \multirow{2}{*}{ Flamingo Denge (sn) } & Erkek & 12 & 47,08 & 14,53 & \multirow{2}{*}{,61 } \\
\hline & $\mathrm{KIZ}$ & 18 & 43,88 & 19,81 & \\
\hline \multirow{2}{*}{ Otur Eriş Sağ (cm) } & Erkek & 12 & 24,50 & 5,12 & \multirow{2}{*}{, $02^{*}$} \\
\hline & $\mathrm{KIZ}$ & 18 & 28,38 & 4,04 & \\
\hline \multirow{2}{*}{ Otur Eriş Sol (cm) } & Erkek & 12 & 25,58 & 4,27 & \multirow{2}{*}{,06 } \\
\hline & $\mathrm{K} \mathrm{IZ}$ & 18 & 28,83 & 4,73 & \\
\hline \multirow{2}{*}{ El Kavrama sağ (kg) } & Erkek & 12 & 20,41 & 2,60 & \multirow{2}{*}{,81 } \\
\hline & $\mathrm{KIZ}$ & 18 & 20,72 & 4,49 & \\
\hline \multirow{2}{*}{ El Kavrama Sol (kg) } & Erkek & 12 & 20,75 & 3,30 & \multirow{2}{*}{,84 } \\
\hline & $\mathrm{KIZ}$ & 18 & 20,50 & 3,72 & \\
\hline \multirow{2}{*}{ Kol Sürati Sağ (sn) } & Erkek & 12 & 18,76 & 4,09 & \multirow{2}{*}{07} \\
\hline & $\mathrm{KIZ}$ & 18 & 15,97 & 4,05 & \\
\hline \multirow{2}{*}{ Kol Sürati Sol (sn) } & Erkek & 12 & 18,53 & 3,25 & \multirow{2}{*}{,16 } \\
\hline & $\mathrm{K} \mathrm{IZ}$ & 18 & 16,69 & 3,74 & \\
\hline \multirow{2}{*}{ Bükülü Kol Asılma (sn) } & Erkek & 12 & 7,20 & 4,88 & \multirow{2}{*}{,82 } \\
\hline & $\mathrm{KIZ}$ & 18 & 6,71 & 7,00 & \\
\hline \multirow{2}{*}{ Mekik Çekme (30 sn) } & Erkek & 12 & 12,00 & 7,42 & \multirow{2}{*}{, 59} \\
\hline & $\mathrm{KIZ}$ & 18 & 13,50 & 7,60 & \\
\hline \multirow{2}{*}{ Dikey sıçrama (cm) } & Erkek & 12 & 19,16 & 3,06 & \multirow{2}{*}{,13 } \\
\hline & $\mathrm{KIZ}$ & 18 & 17,44 & 2,89 & \\
\hline \multirow{2}{*}{ Mekik koşu (20 m) } & Erkek & 12 & 15,16 & 4,68 & \multirow{2}{*}{, $00 *$} \\
\hline & $\mathrm{K} \mathrm{IZ}$ & 18 & 9,94 & 3,28 & \\
\hline
\end{tabular}

$\mathrm{p}<01, \mathrm{p}<0,05$ düzeyinde anlamlılık 


\section{Tartışma ve Sonuç}

Bu araştırmada sporda yetenek seçimi ve spora yönlendirmede 9-10 yaş grubu çocuklarının fiziksel özelliklerinin ve bazı performans profillerinin incelenmesi amacı ile yapılmıştır. Bu nedenle çocuk katılımcılarının fiziksel ve performans özelliklerinin literatürdeki farklı yaş guruplarında fiziksel ve fizyolojik performans verilerinin belirlenmesinde yapılan çalışmalardan Ayan ve Mülazımoğlu (2009), ilköğretim çağı çocuklarından 8-10 yaş grubu olan 1995 erkek gönüllü öğrenci ile

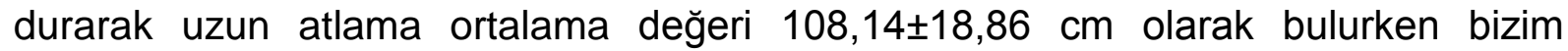
yaptığımız çalışmada erkek öğrencilerin durarak uzun atlama değerinin ortalamasını

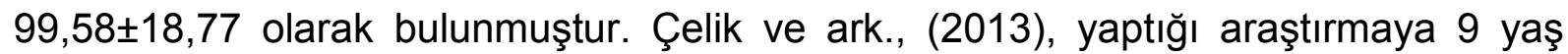
grubu 178 kız, 170 erkek öğrenci katılmıştır. 9 yaş grubunda erkek ve kız çocukların tüm fiziksel özelliklerinde anlamlı farklılık bulunmuştur. 9 yaş grubunda erkek ve kız çocukların motorik özellikleri karşılaştırıldığında sağ ve sol pençe kuvveti, mekik 30 sn parametrelerinde anlamlı farklılık olduğu tespit edilmiştir $(p<0,01)$. Robertson (2017), yapmış olduğu araştırmada Akademik başarı skor puanları (STAAR) ile okuma ve matematik başarılarının fitnessgram ${ }^{\circledR}$ test bileşenlerinden kardiyovasküler zindelik testleri ilişkisini incelemiş sonuç olarak araştırmacı kız-erkek grubunda özellikle kızlarda okuma ve matematik başarı skorlarının kardiyovasküler zindelik testi ile arasında güçlü ve pozitif bir ilişki bulmuştur.

Erikoğlu ve ark., (2009), araştırmalarında 7-12 yaş arası kız ve erkek toplam 203 ilköğretim öğrencisine yaş gruplarına göre Eurofit test bataryası ile performans parametrelerinin değerlendirilmesi yapılmıştır. Sonuç olarak, kız ve erkek çocukların 10 yaşına kadar benzer gelişim gösterdiği, ancak, bu yaştan itibaren erkek çocukların kız çocuklara göre bazı parametrelerde daha yüksek oranda gelişim gösterdiği bulunmuştur.Diker ve ark., (2017), yaptığı çalışmada 9-13 yaş aralığında kız ve erkek olmak üzere 36 çocuğa esneklik testi ve uzun atlama testi yapılmıştır. Sonuç olarak uygulanan testlerde istatistiksel açıdan anlamlı bir fark görülmemiştir. Yaptığımız araştırmada Diker ve diğerleri tarafından yapılan çalışmaya benzer şekilde anlamlı bir fark tespit edilmemiştir ( $p>0,05)$. Hobbs (2014), araştırmada doksan altı beşinci sınıf öğrencisinin aerobik kapasite (PACER) performans testinde sağlıklı fiziksel uygunluk bölgesi (HFZ) gereksinimlerini karşılayan veya karşılayamayan öğrencilerin matematik puanları arasındaki ilişki araştırılmıştır. Sonuç olarak araştırmacı HFZ'yi aerobik kapasite için karşılayan öğrencilere ortalama matematik puanlarının aerobik 
Güçlüöver A., Şahin İN., Gülü M., Esen HT. (2019). Sporda Yetenek Seçimi ve Spora Yönlendirmede 9-10 Yaş Çocukların Fiziksel Özellikleri ve Performans Profillerinin İncelenmesi: Kırıkkale Örneği. Gaziantep Üniversitesi Spor Bilimleri Dergisi, 4(2), 199-210.

kapasite için HFZ' yi karşılamayanların ortalamasından yüksek olduğunu saptamış ve sağlığı arttırıcı bir aerobik kondisyon seviyesine sahip olmanın akademik başarıya olumlu etki ettiğine dair kanıtlar sunmuştur.

Demirel ve ark., (2016), yapmış olduğu çalışmaya 5-6 yaş aralığında 25 çocuk katılmıştır ve araştırma sonucunda öğrencilerin, esneklik, durarak uzun atlama, 30 saniye mekik testi, 10x5 metre mekik koşusu testi, dikey sıçrama sonuçlarında anlamlı bir gelişme saptanmıştır. Bizim yapmış olduğumuz çalışmada 10x5 metre koşu testinde ise anlamlı bir farklılık gözlemlenmemiştir. Bu sonuç bize benzer yaş gurubundaki kız erkek katılımcıların kassal koşu hızlarında benzer morfolojik özelliklere sahip olduklarını göstermektedir. Yenal ve ark., (1999), araştırmaya 10-11 yaş aralığında 20 etkinliğe katılan 20 katılmayan toplam 40 çocuk katılmıştır. Araştırmanın sonucuna göre beden eğitimi ve spor etkinliğe katılan grubun, katılmayan gruba göre disklere vuruş, esneklik, durarak uzun atlama, barfikste asılı kalma, 10x5 metre mekik koşusu, 20 metre dayanıklılık koşunda 0,01 düzeyinde anlamlı bulunmuştur.

Kızılakşam (2006), yapmış olduğu araştırmaya 12-14 yaş grubunda 50 kız ve 50 erkek öğrenci katılmış aktif spor yapan ve aktif spor yapmayan kız öğrencilerin Eurofit Testleri; flamingo denge, disklere dokunma ve otur-uzan testleri karşılaştırmalarında anlamlı farklılıklar tespit etmemiştir $(p>05)$. Fakat bu iki grubun karşılaştırmasında pençe kuvveti sağ ve sol parametreleri arasında $p<0,05$ düzeyinde anlamlı farklılıklar bulunurken, durarak uzun atlama, mekik, bükülü kol ile asılma ve $10 \times 5 \mathrm{~m}$ mekik koşusu karşılaştırmalarında $\mathrm{p}<0,01$ düzeyinde anlamlı farklılıklar gözlemlemiştir. Hasan (2008), 08-11 yaş grubunun 80 erkek, 80 kız denek öğrenci çalışmaya dahil edilerek Eurofit testleri uygulanmıştır. Erkek öğrencilerinin yaş, vücut kütle endeksi, flamingo, disklere dokunma, durarak uzun atlama, pençe kuvveti, 10x5 mekik koşusu testlerinde anlamlı farklılık bulunmamıştır $(p>0,05)$. Kız öğrencilerinin yaş, boy, durarak uzun atlama, pençe kuvveti, 10x5 mekik koşusu testlerinde anlamlı farklılık bulunmamıştır $(p>0,05)$.

Eberline ve ark., (2018), beşinci sınıflar üzerinde yapmış olduğu araştırmada Fiziksel Aktivite İlişkisi (CPAC) ve Fiziksel Aktivite Anketi (PAQ-C) ile çocukların fitnessgram ${ }^{\circledR}$ testlerinden kardiyorespiratuar dayanıklılıkları arasındaki ilişki incelenmiş sonuç olarak fiziksel aktivitenin zevk ve eğlence boyutunda yapılmasının teşvik edilmesi çocukların kardiyovasküler zindeliklerine olumlu etki ettiğini 
Güçlüöver A., Şahin İN., Gülü M., Esen HT. (2019). Sporda Yetenek Seçimi ve Spora Yönlendirmede 9-10 Yaş Çocukların Fiziksel Özellikleri ve Performans Profillerinin İncelenmesi: Kırıkkale Örneği. Gaziantep Üniversitesi Spor Bilimleri Dergisi, 4(2), 199-210.

saptamışlardır. Saraç (2012), yaptığı araştırmaya katılan grupların antrenman öncesi yaş ve boy uzunluğu, Mekik Testi (1/2dk), ölçümleri incelendiği zaman istatistiksel olarak ileri derecede anlamlı farklılık bulunmuştur. $(p<0,001)$ Vücut Ağırlığı $(k g)$, Flamingo denge Testi, Durarak Çift Bacak sıçrama $(\mathrm{cm})$ Mekik koşusu 10x5m ölçümleri incelendiği zaman istatistiksel olarak anlamlı farklılık bulunmuştur. $(p<0,05)$ Bükük Kol Tutma Testi (sn), Reaksiyon Zamanı ms. (Sağ el), Reaksiyon Zamanı ms. (Sol el), Disklere Dokunma Testi (sn), Otur - Eriş Testi (cm) ölçümleri incelendiği zaman istatistiksel olarak anlamlı farklılık bulunamamıştır ( $p>0,05)$.

Yaptığımız araştırmanın sonuçları yukarıda bahsedilen araştırma sonuçları ile paralellik göstermektedir. Bahsedilen araştırma sonuçlarının tamamında çocuk katılımcıların fiziksel uygunluk düzeylerini belirlemek için yapılan Eurofit Testlerinin sonucunda olduğu gibi yaptığımız araştırmanın sonuçlarında da sadece sağ otur-eriş esneklik testinde kızlar lehine $(p<0,05)$ düzeyinde ve kardiyovasküler uygunluk koşu testinde ise $(p<0,01)$ düzeyinde erkekler lehine anlamlı farklılık tespit edilmiştir. Nihai olarak bu sonuçlar bize ilköğretim çağı çocuklarda farklı guruplar açısından yapılan karşılaştırmalarda fiziksel uygunluk ve performans parametreleri arasındaki istatistiksel anlamsızlığın katılımcıların psikomotor becerilerinde özellikle sporla ilgili hareketler döneminde olgunlaşmış temel becerilerinin kuvvet, dayanıklılık, hız, denge gibi özelliklerinde cinsiyet gözetmeksizin performans artışı söz konusudur. Araştırmadan elde edilen bu sonuç çocuk katılımcıların cinsiyetler bakımından benzer özellik ve gelişim düzeylerine sahip olduğunu göstermektedir.

\section{Kaynaklar}

Altınkök, M. (2006). Temel motor hareketlerinin geliştirilmesini içeren özel beden eğitimi program tasarısının 5-6 yaş çocukların temel motor hareketlerinin gelişimine etkisinin araştırılması. Marmara Üniversitesi Eğitim Bilimleri Enstitüsü, Yüksek Lisans Tezi, İstanbul.

Ayan, V., ve Mülazimoğlu, O. (2009). Sporda yetenek seçimi ve spora yönlendirmede 8-10 yaş grubu erkek çocuklarının fiziksel özelliklerinin ve bazı performans profillerinin incelenmesi (Ankara Örneği). FÜ Sağ. Bil. Tıp Der, 23(3), 113-118.

Çelik, A., Günay, E., \& Aksu, F. (2013). 7-9 Yaş Grubu İlköğretim Öğrencilerinin Fiziksel Ve Motorik Özelliklerinin Değerlendirilmesi. Deü Tıp Fakültesi Dergisi. Cilt 27, Sayı 1, (Nisan) 2013, $7-13$. 
Demirel, N., Şirinkan, A., \& Şirinkan, Ş. Ö. (2016). Yaz spor okulunda jimnastik eğitimi alan okulöncesi çağı öğrencilerinin Eurofit testleriyle fiziksel gelişimlerinin incelenmesi (Erzurum örneği). International Journal of Social Sciences and Education Research, 2(2), 850-858.

Diker, G., Zileli, R., Özkamçı, H., \& Sadi, Ö. N. (2017). Genç tenis oyuncularının bazı fizyolojik ve biyomotor özelliklerinin değerlendirilmesi. International Journal of Sport, Exercise \& Training Sciences, 3(1), 25-32.

Docherty, D. (1996). Measurement in pediatric exercise science (pp. 285-334). Champaign, IL: Human Kinetics.

Eberline, A., Judge, L. W., Walsh, A., \& Hensley, L. D.(2018). Relationship of Enjoyment, Perceived Competence, and Cardiorespiratory Fitness to Physical Activity Levels of Elementary School Children. Physical Edu., 75(3), 394-413.

Erikoğlu, G, Özkamçı, H , Golmoghanı, N , Suveren, C , Tot, T, Şahin, N , Selçuk, Z, Zorba, E , Atalay Güzel, N . (2009). 7-12 Yaş Çocuklarda Cinsiyet ve Yaş Gruplarına Göre Eurofit Test Bataryası İle Performans Parametrelerinin Değerlendirilmesi. Gazi Beden Eğitimi ve Spor Bilimleri Dergisi, 14 (4), 49-64.

Hasan, K. (2008). Edirne iline bağlı ilkokullardaki (Şehit Asim İlköğretim Okulu ve Trakya Üniversitesi Devlet Konservatuarı İlköğretim Okulu) 8-11 Yaş Arasındaki Öğrencilerin Eurofit Testleri İle Fiziksel Kondisyonlarının Değerlendirilmesi. Yüksek Lisans Tezi, Trakya Üniversitesi,

Hasırcı, S., Sevimli, D., Durusoy, E.A. (2009). Gelişim ve öğrenme. Ankara:

Heimer, S., Misigoj, M., \& Medved, V. (1988). Some anthropological characteristics of top volleyball players in SFR Yugoslavia. The Journal of sports medicine and physical fitness, 28(2), 200.

Hobbs, M. (2014). Childhood Fitness and Academic Performance: An Investigation into the Effect of Aerobic Capacity on Academic Test Scores. Online Submission.

Karl, K. (2001). Sporda Yetenek Arama Seçme ve Yönlendirme (Çeviri: H. Harputluoğlu). Bağırgan Yayımevi, Ankara.

Kızılakşam, E. (2006). Edirne il merkezi ilköğretim okullarındaki 12-14 yaş grubu aktif olarak spor yapan ve yapmayan (beden eğitimi dersine giren) öğrencilerin eurofit test bataryaları uygulama sonuçlarının karşılaştırııması. (Yüksek Lisans Tezi, Trakya Üniversitesi Sağlık Bilimleri Enstitüsü). 
Molenaar, H. M., Selles, R. W., Zuidam, J. M., Willemsen, S. P., Stam, H. J., \& Hovius, S. E. (2009). Growth diagrams for grip strength in children. Clinical orthopaedics and related research, 468(1), 217-223.

Muratlı, S. (2013). Çocuk ve Spor. Nobel Basımevi, Ankara.

Opstoel, K., Pion, J., Elferink-Gemser, M., Hartman, E., Willemse, B., Philippaerts, R., ... \& Lenoir, M. (2015). Anthropometric characteristics, physical fitness and motor coordination of 9 to 11 year old children participating in a wide range of sports. PloS one, 10(5), e0126282.

Pekel, A. (2007). Olarak 10-12 Yaş Grubu Çocuklarda Bazı Değişkenler Üzerinde Normatif Çalışma. Doktora Tezi. Ankara: GÜ Sağlık Bilimleri Enstitüsü.

Robertson, J. (2017). The Relationship between Physical Fitness and Academic Achievement for Fourth Grade Students in Southeast Texas. ProQuest LLC. 789 East Eisenhower Parkway, PO Box 1346, Ann Arbor, MI 48106.

Sallis, J. F., \& Patrick, K. (1994). Physical activity guidelines for adolescents: consensus statement. Pediatric exercise science, 6(4), 302-314.

Saraç, H. (2012). Futbol Branşında 12-15 Yaş Gurubu Erkek Çocukların Fiziksel Gelişiminin Eurofit Test Bataryasıyla Değerlendirilmesi. Y. Lisans Tezi, Erciyes Üniversitesi Sağlık Bilimleri Enstitüsü, Kayseri.

Tutkun, E. (2002). Samsun İli İlk Öğretim Çağı Çocuklarının Yetenek Seçim Yönteminin Geliştirilmesi. On Dokuz Mayıs Üniversitesi, Doktora Tezi. Samsun Tutkun, E. (2007). Futbolda Yetenek Seçimi Modelleri. Akademi Basın ve Yayıncılık. İstanbul.

Uzuncan, H. (1991). Eurofit testleri ile 10-12 yaşları arasındaki erkek öğrencilerin aerobik güç ve fiziksel uygunluklarının ölçülmesi. Yayımlanmamış yüksek lisans tezi. Selçuk Üniversitesi. Sağlık Bilimleri Enstitüsü. Konya.

Yenal, T. H., Çamlıyer, H., \& Saracaloğlu, A. S. (1999). İlköğretim İkinci Devre Çocuklarında Beden Eğitimi ve Spor Etkinliklerinin Motor Beceri ve Yetenekler Üzerine Etkisi. Gazi Beden Eğitimi ve Spor Bilimleri Dergisi, 4(3), 15-24.

Zahner, L., Puder, JJ., Roth, R., Schmid, M., Guldimann, R., Pühse, U., Knöpfli, M., Braun-Fahrländer, C., Marti, B., Kriemler, S. A. (2006). School-Based Physical Activity Program to Improve Health And Fitness in Children Aged 6-13 Years "Kinder Sport studie KISS": Study Design of A Randomized Controlled Trial. BMC Public Health, 6(6): 147. 